\title{
Western Textbook Theory and the Developing Countries
}

\section{ANTHONY BOTTOMLEY*}

This paper deals with the adaptation of traditional Western textbook economic theory to the problems of developing countries. It treats wages, rents and interest together with Keynesian and classical economy-wide models from this standpoint. The value of labour's marginal product will vary with the wage, rents with the land tenure system and interest rates with the size of and security on a loan. Inflationary Keynesian-inspired growth is likely to be unacceptable. Advance must therefore occur in a supply-originated classical manner.

Why and in what way has established Western economic theory failed to meet the requirements of developing countries? This question is best answered in terms of the degree to which we are still unable to produce a comprehensive textbook such as that of Samuelson or Lipsey which relates easily to the problems of underdeveloped countries. In other words, we want to know what specifically requires adaption in, first, established micro-economic and, second, macro-economic theory if they are to be directly applicable to the Third World? We shall deal with each of these in turn.

\section{MICRO THEORY}

Micro theory can be broken down into: (1) supply and demand analysis, (2) the theory of the firm, (3) distribution theory, and (4) project appraisal.

\section{Supply and Demand}

"Teach a parrot to say 'supply and demand' and you will have a political economist." So said Carlisle, and like all good aphorisms this one has stuck since there is some small truth in it. Supply and demand analysis travels much better from North to South or from West to East than does any other section of economic theory.

Most Pakistani economists would agree with Western advisers that if the Nation's water-intensive sugar is priced above world-market levels and water below the costs of its provision, then more irrigated acreage will go into sugar production than is desirable; that if trade in grain between districts is confined to official prices which are lower than world prices, then surplus districts will reduce their grain production below what comparative advantage would dictate. At least this will be 
true unless convincing shadow prices and external economies can be adduced in support of such policies. Thus, Western supply and demand analysis is applicable to the problems of the Third World, subject to some well-known reservations.

\section{The Theory of the Firm}

It is hard to see what alterations could be made in the theory of the firm so as to make it more applicable to the problems of developing countries. Certainly tariff protection has allowed more firms to come into an industry than might really be needed in a developing country and such firms do seem to operate at alarmingly low levels of capacity; see [6] and [23]. But even given tariff protection, it is not clear why competition does not eliminate such waste. Perhaps the answer lies in the fact that the market for widgets or whatever in most developing countries is still so small that producers remain few and can easily form cartels to protect their inefficient operations through high, protected prices. But in that event the theory of monopoly provides an adequate explanation, given the addition of the constraint imposed by the high competing protected import price. Other explanations have been adduced which refer to the theory of imperfect competition with concomitant low level equilibria, but they lack conviction and the matter needs further examination.

The theory of the firm in poor countries could, however, be brought into line with project appraisal in particular and welfare economics in general if textbooks showed how cost and revenue structures might alter if shadow, rather than money prices were used. Shadow prices might be equated, at least in theory, with border prices to show how prices, levels of output and numbers of firms in an industry would vary under a regime of free trade in goods and money, although the practical application of border pricing is difficult not the least because a wide variety of assumptions are equally plausible in this respect; see [32, esp. the papers by Stephen Guisinger and T. N. Srinivasan].

\section{Distribution Theory}

Here considerable refinements of Western theory can be made. They are best discussed under: (a) wages, (b) rents, (c) interest, and (d) profits.

(a) Wage theory in developing countries needs to take account of the fact that productivity can vary markedly with the wage, equilibrium being reached when an increment in the wage is matched by the resulting increase in production. It can be argued that this is of greater significance in developing than in developed countries because malnutrition and lack of worker cooperation, particularly in the form of absence at harvest time, arise from low wages. Employers in industry and on plantations simply cannot afford to have expensive machines or crops mishandled by a hungry and disgruntled work force when substantial wage increases from very low levels would not raise overall costs to any marked degree. This, no doubt, explains why industrial and plantation wages are three to four times those obtained in indigenous agriculture and the wage/productivity ratio can easily be incorporated into existing theory; see [19] and [20].

(b) Rents will be determined differently from Ricardian principles if land is sharecropped, if some of it is held in common or if large landowners monopolise isolated markets; but all these issues can be expounded using the standard tools of distribution theory if they are suitably modified.

Sharecropping does not, in the end, lead away from a neo-classical optimum [16], but common ownership does cause the concentration of capital and labour on such land as is privately held to an undesirable degree [15]. Monopolistic land ownership, of course, leads to higher prices and lower levels of production than is desirable, but the concept of the marginal revenue product, when combined with a marginal supply price for land, adequately explains this phenomenon [7]. The problem is that these issues have not yet found their way in customary diagrammatic form into textbooks on economic development.

(c) Interest theory will not vary between poor and rich countries where the pure rate is concerned [11], but premia for risk, administration and monopoly profit (usury) do play a much larger role in the uncertain conditions and isolated markets for small rural and urban loans $[4 ; 17 ; 18]$. Small loans, which are hard to recover, cost a lot to administer [10] ; risk premia are high for institutional lenders outside the village [13] and make it difficult for them to encroach on the local userer's monopoly profit [8]. But all these things are easy to explain using the orthodox theory of the firm to make supply prices for credit, although the demand side is complicated by the fact that much borrowing in the unorganised money market is for ceremonial and other consumer purposes and is unrelated to any value of the marginal product on an investment arising from the loan.

(e) Profits are arrived at in the same way the whole world over and exising Western theory adequately explains the process, except that the now familiar tradeoffs between profits and the easy life or profits versus expansion and consequent power accumulation do not begin to encompass all the social issues which constrain profit-maximisation in village societies.

Further, this trade-off between profits and real or imagined risks needs much closer attention in any discussion of the speed and efficiency with which innovations may spread, particularly in agriculture [9].

\section{Project Appraisal}

Project appraisal has received close attention where developing countries are concerned. Its border price refinements of shadow-pricing [26;32] threaten to take it out of the realm of practical use. But more serious, perhaps, is the failure of established project appraisal techniques to provide a workable method for taking account of backward and forward linkages outside the boundaries of the project 
under review $[2 ; 12]$. Then, too, of vital importance in certain industrial projects, in particular in generating the entrepreneurial drives as well as a supply of skilled labour, are external economies which are virtually impossible to quantify in the appraisal of a project. Nevertheless, the bulk of the social return may lie therein. But there is no easy solution to this problem.

\section{MACRO THEORY}

Macro-economics is customarily divided into: (1) neo-classical theory, (2) Keynesian economics, (3) structural growth economics, and (4) international trade.

\section{Neo-classical Theory}

Most macro-economic sections of Western textbooks begin with a discussion of neo-classical economics. The neo-classicists concluded that increased supply would create its own demand through adjustments in the labour and loanable-funds markets. But the price of the goods being supplied could fall in the process. Nevertheless, if the money supply is expanded, a constant overall price level throughout the economy can be maintained at a higher level of production. Economic growth will take place.

This process can best be modified with respect to developing countries by reference to the supply of and demand for goods and services alone. Additional supply allows additional demand through the creation of additional money. This money will be used to finance further transactions in what we can call: (a) inititation and (b) response goods and services.

(a) Initiation occurs when the supply of a particular good or service increases over the whole range of possible prices for it. We may use the introduction of Mexican wheat as an example. But this is a simplification since we assume that wheat, not bread, is the final good which appears in the national income accounts.

As the new varieties are introduced, more can be supplied at each level of factor employment. The supply of wheat moves from $S$ to $S_{1}$ in Figure 1-A. Its price falls from $\mathrm{OL}$ to $\mathrm{OG}$. This is commensurate with the equilibrium at $\mathrm{H}$. But the monetary authority wishes to encourage growth at a constant overall price level. The reduction in the price of this staple item of diet therefore allows them to expand the money supply. The added money creates further income. There will thus be an increase in the demand for wheat itself (from $D$ to $D_{1}$ ) in accordance with the income elasticity of demand for it. The price of wheat will rise to $\mathrm{OX}$ with the final equilibrium at $\mathrm{U}$. In reality, this will be a continuous process rather than sequential and the equilibrium in the wheat market should move directly from $\mathrm{M}$ to $\mathrm{U}$.

(b) Response goods and services are produced when prices per unit of output rise above costs as a result of monetary expansion. We may clarify this if we assume a two-good economy in Figure 1: the initiation good-wheat (1-A)-and a composite representing all response goods and services-widgets (1-B). We define units of each

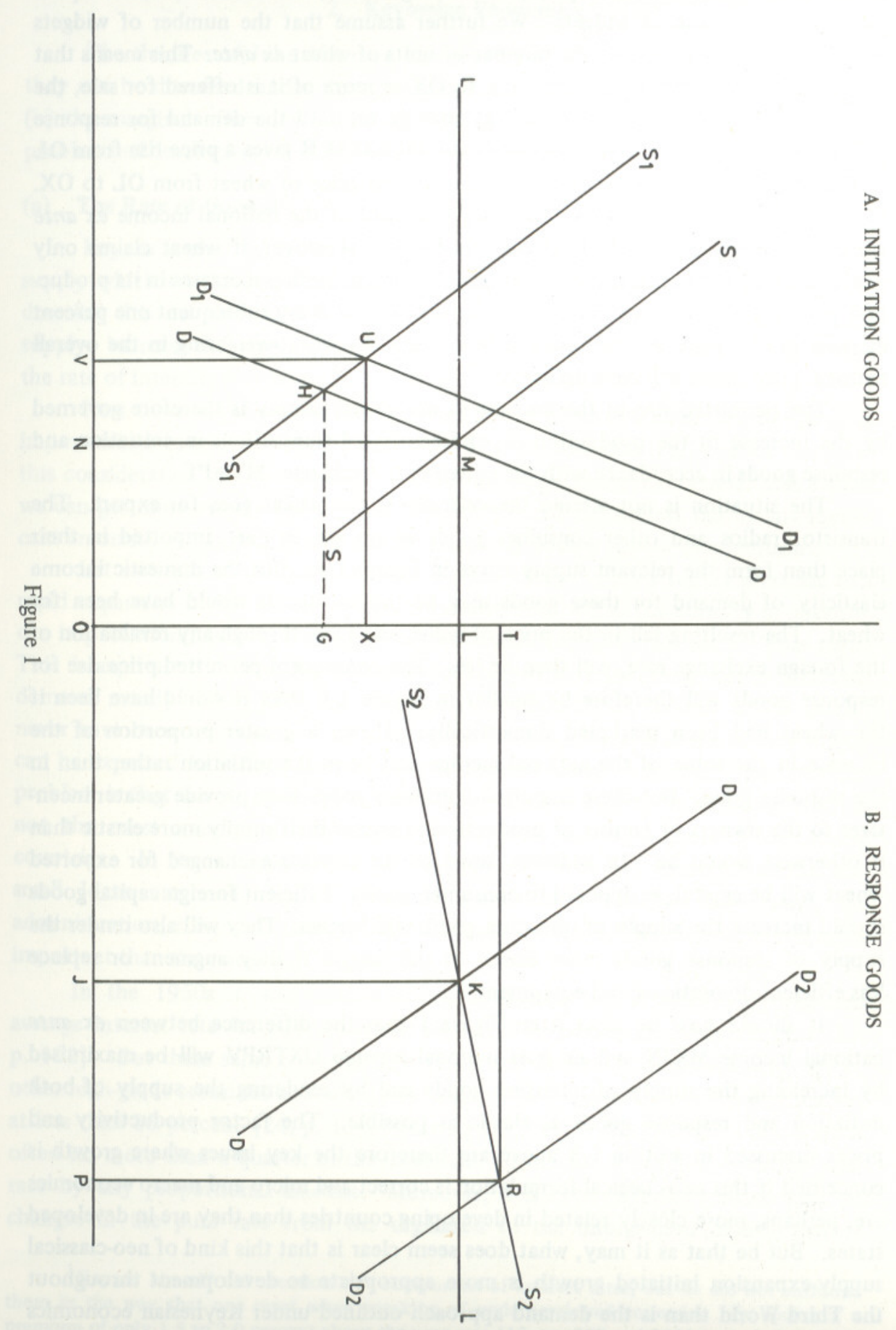


so that both sell at the same price, OL, to begin with; one bushel of wheat equals five-eighths of a ton of widgets. We further assume that the number of widgets produced and sold is double the number of units of wheat ex ante. This means that when the price of wheat falls from OL to OX as more of it is offered for sale, the associated increase in the money supply may go on until the demand for response goods rises to $D_{2}$. The new equilibrium for widgets at $R$ gives a price rise from $O L$ to OT which is only one-half of the decline in the price of wheat from OL to OX. This is so because wheat sales form only one-third of the national income ex ante while response goods, widgets, form two-thirds. Moreover, if wheat claims only one-quarter of the national income ex post, then any further increases in its production must allow of a three percent fall in its price for every subsequent one percent increase in the price of response goods because the wheat-weighting in the overall national price index will have declined.

The permitted size of the increase in the money supply is therefore governed by the increase in the production of, and associated transactions in, initiation and response goods in accordance with the equation of exchange: MV=PT.

The situation is not altered theoretically if the wheat goes for export. The transistor radios and other consumer goods which are, in part, imported in their place then form the relevant supply curve in Figure 1-A. But the domestic income elasticity of demand for these goods may be higher than it would have been for wheat. The resulting fall in the price of radios and such, through any revaluation of the foreign exchange rate, will then be less. The consequent permitted price rise for response goods will therefore be smaller in Figure 1-B than it would have been if the wheat had been marketed domestically. Hence a greater proportion of the increase in the value of the national income will be in the initiation rather than in the response good. But these imported consumer goods may provide greater incentives to the owners of factors of production to render their supply more elastic than it otherwise would be. In addition, some of the imports exchanged for exported wheat will be capital, as opposed to consumer, goods. Efficient foreign capital goods should increase the supply of initiation goods still further. They will also render the supply of response goods more elastic at the margin if they augment or replace less efficient domestic capital equipment.

It should now be clear from Figure 1 that the difference between ex ante national income MKJN and ex post national income UXTRPV will be maximised by increasing the supply of initiation goods and by rendering the supply of both initiation and response goods as elastic as possible. The factor productivity and prices discussed in section I. 3 above are therefore the key issues where growth is concerned if this neo-classical formulation is correct and micro and macro economics are, perhaps, more closely related in developing countries than they are in developed states. But be that as it may, what does seem clear is that this kind of neo-classical supply-expansion initiated growth is more appropriate to development throughout the Third World than is the demand approach outlined under Keynesian economics in the next Section.

\section{Keynesian Economics}

The theories of John Maynard Keynes figure largely in Western textbooks and they can be discussed under three broad headings. They are: (a) the rate of interest, (b) the marginal efficiency of capital, and (c) the multiplier. Each relates to the problems of developing countries with varying degrees of inappropriateness.

\section{(a) The Rate of Interest}

Keynes argued that it was the whole demand for money to hold and its entire supply which set the rate of interest. His liquidity preference schedule was used to describe this demand, and coins, paper currency and demand deposits the whole supply. Increase the supply of money, the argument ran, and you will at once reduce the rate of interest. But how true is this of the Third World?

First there are the well-known difficulties of exercising credit control at all in impoverished countries. Money can always be printed, however, and we can leave this consideration on one side as far as monetary expansion is concerned. But even if we can get more money into circulation, will the rate of interest fall by any significant amount? An answer to this question depends upon a variety of conditions.

Let us begin by assuming that an increase in the money supply gives rise to a rapid expansion in the supply of goods and services, or that the country in question can import more, and that no expectations of a general price rise occur. What then? This is equivalent to the Keynesian situation, properly speaking, where increased demand merely unites hitherto idle capital equipment and labour which should never have been split asunder. In these circumstances, increases in the money supply can be expected to reduce the pure rate of interest along traditional lines. But, the problem is that the pure rate of interest-the reward for sacrificing liquidity-is often not the most important component of the total rate of interest in developing countries. In the unorganised money market where money lenders predominate, small loans are made against little or no security. As we have seen, the administration, risk, and monopoly profit (usury) components may be much more important than the pure rate. ${ }^{1}$

In the 1950s it was authoritatively estimated that a world-wide-weighted average interest rate for poor countries lay between 24 and 26 percent a year [33, p. 102]. But these same countries can often find a market for government bonds, other high-grade securities and savings deposits in the organised, urban money market at less than 10 percent $[24 ;$ p. 134 , Table 2]. Thus it is that Keynes's pure rate is often no more than a quarter of the total rate. Changes in it will not affect the total rate by any proportional amount. Moreover, it is extremely difficult to pass on changes in the pure rate from the organised to the unorganised money market

${ }^{1}$ Keynes himself did mention risk component of interest rates, but he did not enthrone them in the way that one must when speaking of underdeveloped countries. He spoke of a premium of only 1.5 to 2.0 percent above the pure rate [13, pp. 208 and 309]. 
because of the lack of contact between the two, and because of the desire on the part of the village money-lender to limit the inflow of funds in order to maintain his monopoly profits. ${ }^{2}$

Thus it is that changes in the pure rate in the organised money market will not be directly influential in the rural sector of the economy, where interest rate reduction is of paramount importance. However, this does not mean that increases in the money supply will have no effect at all upon the rural rate of interest. If they lead to inflation, farmers in particular will probably be able to get more for their produce in real terms because of its short-run inelasticity of supply. Their crisis-ridden demand for loans will decline, their collateral or surplus will increase, and they will be in a stronger position the next time that they approach the moneylender; always providing, that is, that the landlord is unable to appropriate their gains. This can lead to reductions in the rural rate of interest at the same time as interest rates are rising in the towns due to expectations of further price rises $[33, \mathrm{p} .105]$. These reductions may be even greater if the inflationary pressures help spread the use of money throughout the rural economy, since there appears to be a definite inverse correlation between the degree of monetisation in a particular area and the prevailing rate of interest which moneylenders can impose [29, pp. 191-193].

\section{(b) The Marginal Efficiency of Capital}

In the Keynesian framework the elasticity of the marginal efficiency of capital (MEC) schedule can be used to relate the degree of change in the rate of interest to the degree of change in the level of investment. But how useful is this concept where impoverished nations are concerned? Again, we must try to answer this question by dividing our discussion between the developed, capitalist section of the economy and the areas in which traditional modes of production persist.

\section{The Capitalist Sector}

Many poor countries have some well developed economic sectors. Plantations, mines, industry, some construction, and the import-export trade normally belong to this category. Here borrowing is for profit, and the demand for capital will be its expected rate of return at different levels of investment, or its marginal efficiency.

This MEC schedule will normally be the more interest-elastic the closer the expectations come to being fulfilled. In other words, the less risky an investment, the more likely is a reduction in the rate of interest to bring it into being. On the other hand, where the possibility of large profits or losses exists changes in the rate of interest will not be very influential where investment decisions are concerned.

There is a strong tendency in underdeveloped countries for capital to stay within the fields which borrowers and lenders already know: i.e. where the risk is least. Thus it is that one continually hears of the refusal of traders to transier

${ }^{2}$ Only 28 percent of the moneylenders in an All-India Rural Credit Survey of the same period $[29$, p. 78$]$ expressed the desire to import funds in addition to their own reserves. their efforts and resources into industry, of the preference of plantation and mine owners for similar investment in another country once local opportunities have been exhausted [27, pp. 155 et. seq.], and of considerable overcapacity in luxury housing and existing industries. What, then, is likely to be the effect of an increase in the supply of money and of lower rates of interest in this capitalist sector?

The answer is, first, that trading may become more competitive. This could benefit the general populace, particularly if it resulted in the extension of more credit or higher prices to the suppliers of raw materials. But these activities are so monopolistic that changes in the supply of money and the rate of interest are not likely to be felt outside the trading community itself. Plantation and mine owners, too, may be tempted to extend their operations. But if the cost of money falls sufficiently in the developing country in question, they, along with others, may choose to borrow there in order to lend or invest abroad where rates are higher, and this is rarely to be desired.

Luxury housing and industry, however, generally present a separate problem. They normally operate under conditions of considerable over-capacity. Economists are often puzzled by the large numbers of well-appointed apartments which remain unoccupied, while at the same time the very high level of rents does not decline. In these curious conditions, easier money and lower interest rates might easily increase the rate of unnecessary building even more if the returns at the margin are predictable.

Industry, too, presents a similar picture. Once a particular type of factory has been established, imitations quickly follow suit. Textile producers will proliferate, but no one can be found to produce the plastic buttons which will also be required. The explanation is simple. Familiarity breeds confidence. The necessary knowledge and skills become available within a country once the first factory has been established. They need only be bid away from the original producer. As has been said, a situation quickly arises in which nearly all plants operate at less than 50 percent of their capacity, while the prices of their finished products remain very high indeed. Producers show all the unwillingness to compete which is associated with the kinked demand-curve analysis embodied in the theory of imperfect competition.

Easier credit and lower rates of interest may only serve to aggravate this situation. Entirely new enterprise will be risky, and will involve relatively interestinelastic MEC schedules, so that lower rates of interest are not likely to be a strong factor in their inauguration. Of course, easier credit conditions may not reflect themselves so much in lower interest rates as in a relaxation of the security requirements imposed upon the borrower. This may favour the relatively insolvent innovator, but it should never be relied upon. Easier credit, with or without lower interest rates, may allow property-developers and existing factory-owners as well as people who wish to invest abroad to bid resources away from those who need them most. Central banks should always examine this situation very closely before they decide to initiate a monetary expansion. 


\section{The Traditional Sector}

This sector comprises peasant farming, artisan production, and so forth Here the demand curve for loans is almost certain to be highly interest-inelastic. The problem is that it rarely coincides with the borrower's estimate of his margina efficiency of capital. Borrowing is crisis-ridden. Loans are made to tide the family over to the next harvest, to finance a funeral or a wedding, and so on. The money must be obtained no matter what the cost. (For example, in times gone by, approximately half of total borrowing in India appeared to have been for immediate family expenditures $[30$, p. 24$]$, and in some States the proportion rose to more than 70 percent [33, pp. 81 and 113].) Moreover, as we have seen, the reward for sacrificing liquidity constitutes a relatively small proportion of the rate of interest at the village level. So it is that increases in the money supply which affect only the pure rate are not likely to be directly influential in stimulating production and employment, even if they can be passed on to the traditional sector.

Once the farmer begins to borrow money for the use of fertilizer rather than simply in order to keep his family alive until the next harvest, or to entertain his relatives and friends, he will have entered into a phase of rational investment. Then his marginal efficiency of capital schedule will become more and more the arbite of whether or not he should obtain a loan. This kind of decision too will itself reduce the rate of interest he must pay. He will borrow more and more and the administration cost on each unit loaned will thus decline. He will become less and less of a credit risk as his investments bear their fruit, and the lender's premium against default can be progressively reduced. Finally, his improved position may allow him to borrow from a bank, thus eliminating whatever monopoly profit (usury) may previously have existed at the village moneylender level. This process will be cumulative until the Keynesian rate of interest alone, i.e. the reward for sacrificing liquidity, becomes operative in investment decisions in the formerly traditional sector.

\section{(c) The Multiplier}

The applicability of this part of the Keynesian theory in poor countries was originally contested by V.K.R.V. Rao [31]. Following upon his paper, a consensus has arisen that there is little or no real multiplier effect from an investment in a poor country because of the inelasticity of supply of the principal consumer commodity food. ${ }^{3}$ It is therefore useless, so the argument goes, to apply the Keynesian remedy to the underemployment and unemployment situations which obtain in poor coun tries, as any multiplier effects will be largely felt in higher prices and/or balance-ofpayments difficulties, as opposed to secondary increases in production and employment.

${ }^{3}$ For some empirical support of this assertion in Pakistan and India in the past, see [21, p. 590] and [25, Table II, p. 368]
But all this really depends upon what kind of investment is made and how long its gestation period is likely to be. There are countless opportunities in underdeveloped countries for investment which will yield an output of several times the value of the money capital involved in a very short period of time. The use of fertilizers constitutes an arch-example of this. In the United States, some twenty years ago, it was estimated that at least one-third of the value of agricultural production could have been attributed to the use of commercial fertilizers, while their cost totalled only about 6 percent of the nation's farm outlays [28, pp. 959-960]. This signifies that credit expansion for fertilizer loans can quickly be countered by increases in output sufficient to absorb the new money, even where a substantial multiplication of demand occurs. Then, too, meagre units of money capital can often be combined with considerable quantities of underemployed labour. If the latter are working for themselves they will probably not demand any immediate return on their effort.

So it might be that as the multiplier effects of a relatively small amount of money capital invested work themselves through the economy on the demand side, a concomitant value of goods is added to supply. Thus money can be created for certain kinds of investment with little or no inflationary results. Moreover, as we have seen, there is normally a good deal of slack in many parts of the capitalist sector of a poor country's economy which might also be used to meet a growing demand. This is also probably true of parts of the traditional sector such as artisan production and small-scale manufacturing. Of course, any productive investment is likely to increase output more than demand in terms of constant values in the long run, but there will probably be an interim inflation if credit is expanded for its creation. Once the new price level has been established it will generally be both difficult and undersirable to return to the old. The new level of monetary demand must therefore be maintained, and the investment distortions arising from inflation may more than cancel out the initial gains achieved.

\section{Structural Growth Economics}

Structural-growth economics really begins with the so-called balanced-growth theory. If increased demand at the margin is not entirely or even largely for the output of existing, under-capacity industries, then it will result in the added imports, balance-of-payments deficits and quickly arrested development of a two-gap (capital and foreign exchange) variety. One supposed answer here is to quickly create import-substituting industries in such a way that they and their workers provide savings for one another's investments and a market for one another's output as well as a market for additional production in agriculture. But, as has been said so often, this is a contradiction in terms. If an economy had the capital, the skills and the entrepreneurial drives to do this, then it would not be underdeveloped in the first place.

It has therefore become customary to contrast the above balanced-growth theory with Albert Hirschman's unbalanced or linkage-growth theory [22]; the 
creation of a steel mill encourages the production of coking-coal on the input side and the manufacture of bicycles on the output side. The whole can be neatly encompassed within the framework of Leontief's input-output table in the familiar form of Western textbook expose, and it is true that these tables are increasingly used as an instrument of macro-planning throughout the world with virtually all of the 90 or so countries with any population size having constructed them [5].

But, while it is a fact that the creation or expansion in the output of an industry will enlarge the demand for the outputs of other industries, these outputs are frequently supplied at artificially high protected prices. Then, too, the domestic production of steel, for example, will rarely lead to the establishment of a bicycle industry. If the country in question enjoys a comparative advantage in the production of bicycles, this industry is likely to exist already on the basis of imported steel. The advent of a protected domestic substitute supply will do no more than raise the price of steel and bicycles and the advantage for domestic growth and employment remains unclear. This theme has many variations. In Pakistan, for example, the creation of a domestic spinning industry has led to periodic embargoes on the export of cotton so as to keep down the domestic price of yarn. This, coupled with the protected price for sugar mentioned at the outset, can lead to an increase in irrigated cane growing at the expense of an artificially reduced cotton production; so much for backward-and forward-linkage strategies in practice. Then, too, the mechanics of the input-output table completely miss the degree to which activity in one sector stimulates activity in another through the provision of transferable entrepreneurial drives and skills as well as the external economies which one sector may provide to another as a consequence of fuller capacity operation and lower prices. Such things are, it seems, at the heart of material advance, not the mechanical input co-efficients which go to make up an inter-industry flow matrix.

\section{International Trade}

Traditional theory argues that if a country abides by the law of comparative advantage, which can be so neatly summarised in any textbook exposition, then it will prosper. The infant industry argument provides temporary relief from the rigours of this dictum. But the import-substitution policies of the last thirty years have exploited the infant-industry escape clause well beyond the time which might reasonably be required for an industry to reach maturity.

The so-called "outward-looking" growth strategy has grown up in opposition to this "inward-looking" approach. Essentially, the argument is that a country should do those things which it does best and export the resulting output in exchange for goods which it produces less efficiently; naked comparative advantage. All this is implied by the theories of effective rates of protection [1], domesticresource-cost-ratios [3] and border-price project appraisal [26], although the latter does attempt to take some external economies into account, but not the important ones of entrepreneurial drive, skill creation and attitude change associated with a particular project. Without an initially inefficient cotton-spinning industry there may be no industrially-orientated entrepreneurs or craftsmen to found a potentially efficient electronics industry and so on and an economy's development may be arrested at the raw-material provision stage.

It is, then, not a question of an inward- or outward-looking growth strategy, but of where the balance of advantage lies, and as yet no technique for evaluating the trade-offs between them, which takes account of the really important external economies, has been devised. Such an enumeration of trade-offs and their expression in formula terms is, of course not impossible, but it does not appear likely that they can be calculated with any accuracy in practice or neatly embodied in the simple diagrammatic representation which lies at the core of Western textbooks.

\section{CONCLUSIONS}

It does seem that, by and large, appropriate adaptions can be made to Western micro-economic theory so as to render it directly applicable to the problems of developing countries.

With respect to macro-theory, however, the outlook is less promising. The Keynesian analysis, which still lies at the heart of Western macro-texts, was found wanting in developing countries thirty years ago and is now scarcely more promising as a solution to the current problems of developed states.

The difficulty is that a solution to the problem of economic growth in the poorer parts of the world probably lies largely outside the field of economics. There have been, and still are, ethnic groups in different parts of the world whose nations reach maturity; yesterday the Europeans and their American offshoot, today the Japanese, tomorrow the Overseas Chinese. But if those factors upon which economic theory can throw light can create the basic conditions in which such people can flourish, they do not, of themselves, furnish the spirit of the times which is the essence of economic growth; the will to create, to organise and to learn in a materially productive way.

If there is any consolation for the economist in all this, it is that if he can guide policy makers so as to provide a legislative and bureaucratic framework in which some growth can take place, then this in its turn will help generate the appetites and attitudes of mind which will cause that growth to flower. The fertility of the soil from which this life is drawn will vary according to the national characteristics which have developed up to here and now. In other words, the application of "sound" economic principles can get the growth process started and facilitate its continuation, yet this does not constitute the combustible material itself. The fire of economic growth, to change the metaphor, will burn more or less rapidly according to the nature of the people who seek material advance, but we are a long way from being able to expound what this nature is, let alone how it might be created in traditional economic terms. 


\section{REFERENCES}

1. Balassa, B., and D. M. Schydlowsky. "Effective Tariffs, Domestic Cost of Foreign Exchange and the Equilibrium Exchange Rate". Journal of Political Economy. May-June 1968.

2. Bell, Clive, and Shantayanan Devarajan. "Towards a Synthesis of Semi-InputOutput and Little-Mirrlees: A Social Cost-Benefit Analysis with Multiplier Effects of An Irrigation Project in Northwest Malaysia". Pakistan Development Review. Vol. XVIII, No. 2. Summer 1979.

3. Bruno, M. "The Optimal Selection of Export-Promoting and Import-Substituting Projects". In United Nations, Planning the External Sector: Techniques, Problems and Policies. New York. 1967.

4. Bottomley, Anthony. "A Monetary Strategy for Underdeveloped Rural Areas”. Journal of Agricultural Economics. September 1966.

5. Bottomley, Anthony. "A Sixty Sector World Input-Output Model”. Essays in Honour of Giovanni Demaria. Padova: CEDAM. 1978.

6. Bottomley, Anthony. "Imperfect Competition in the Industrialisation of Ecuador". Inter-American Economic Affairs. Summer 1965.

7. Bottomley, Anthony. "Monopolistic Rent Determination in Underdeveloped Rural Areas”. Kyklos. Fasc. 1. 1966.

8. Bottomley, Anthony. "Monopoly Profit as a Determinant of Interest Rates in Underdeveloped Rural Areas". Oxford Economic Papers. October 1964.

9. Bottomley, Anthony. "Profits and Growth in Underdeveloped Rural Areas". Weltwirtschaftliches Archiv. Band 102, Heft 2. 1969.

10. Bottomley, Anthony. "The Cost of Administering Private Loans in Underdeveloped Rural Areas". Oxford Economic Papers. July 1963.

11. Bottomley, Anthony. "The Determination of Pure Rates of Interest in Underdeveloped Rural Areas". Review of Economics and Statistics. August 1964.

12. Bottomley, Anthony. "The Inclusion of Secondary Benefits in Rates of Return on Irrigation Projects". Bulletin of the International Commission on Irrigation and Drainage. (Forthcoming).

13. Bottomley, Anthony. "The Premium for Risk as a Determinant of Interest Rates in Underdeveloped Rural Areas". Quarterly Journal of Economics. November 1963. ["Reply" on above in the same Journal, May 1965].

14. Bottomley, Anthony. "The Structure of Interest Rates in Underdeveloped Rural Areas". Journal of Farm Economics. May 1964.

15. Bottomley, Anthony, and Colin Baxter. "Potential Gains on the Enclosure of Common Land in Poor Countries". Journal of Agricultural Economics. May 1968. ["Reply" on the same Subject in the same Journal, January 1971]

16. Bottomley, Anthony, and Colin Baxter. "Rent Determination with Share
Cropping in Underdeveloped Countries". Journal of Agricultural Economics. May 1970.

17. Bottomley. Anthony, and Donald Nudds. "A Widow's Cruse Theory of Credit Supply in Underdeveloped Rural Areas". Manchester School of Economics. June 1969.

18. Bottomly, Anthony, and Donald Nudds. "Interest Rate Determination in Underdeveloped Rural Areas". American Journal of Agricultural Economics. May 1975.

19. Bottomley, Anthony, and John Moes. "Wage Rate Determination with Limited Supplies of Labour in Developing Countries". Journal of Development Studies. April 1968.

20. Bottomley, Anthony, and John Moes. "Wage Rate and Employment Determination in Underdeveloped Countries". Malayan Economic Review. October 1978.

21. Falcon, W. P. "Farmes Response to Price in a Subsistence Economy: The Case of West Pakistan". American Economic Review, Papers and Proceedings. Vol. LIV. May 1964.

22. Hirschman, Albert. The Strategy of Economic Development. New Haven, Conn. (USA): Yale University Press. 1960.

23. Kemal, A. R., and Talat Alauddin. "Capacity Utilisation in Manufacturing Industries of Pakistan". Pakistan Development Review. Vol. XIII, No. 3. Autumn 1974.

24. Khan, Muhammad Zubair. "Estimation of Shadow Prices for Project Evaluation in Pakistan". Pakistan Development Review. Vol. XVIII, No. 2. Summer 1979.

25. Khatkhate, D. R. “The Impact of Inflation on India's Economic Development". Economic Development and Cultural Change. Vol. VII. 1958-59.

26. Little, I. M. D., and J. A. Mirrlees. Project Appraisal and Planning for Developing Countries. London: Heinemann Educational Books Ltd. 1974.

27. Puthucheery, J. J. Ownership and Control in the Malayan Economy. Singapore: Eastern Universities Press. 1960.

28. Renshaw, Edward F. "Distributed Lags, Technological Change and the Demand for Fertilizer". Journal of Farm Economics. Vol. XLIII. November 1961.

29. Reserve Bank of India. All India Rural Credit Survey. Vol. II. Bombay. 1954

30. Reserve Bank of India. Summary of the Report: All India Rural Credit Survey. Bombay. 1955.

31. Rao, V. K. R. V. "Investment Income and the Multiplier in Underdeveloped Countries". Indian Economic Review. Vol. I. February 1952.

32. "Symposium on Shadow Pricing". Pakistan Development Review. Vol. XVIII, No. 2. Summer 1979.

33. Wai, U. Tun. "Interest Rates Outside the Organised Money Markets of Underdeveloped Countries". Staff Papers of the International Monetary Fund. Vol. VI. 1957-58. 